\title{
Supersack Dosing Unit
}

National Cancer Institute

\section{Source}

National Cancer Institute. Supersack Dosing Unit. NCI Thesaurus. Code C62420.

A dosing unit equal to the amount of inert ingredient(s) contained in a supersack. 